\title{
ANALISIS NILAI TAMBAH KERIPIK PISANG KEPOK DAN SISTEM PEMASARAN PISANG KEPOK (Musa paradisiaca) DI KABUPATEN PESAWARAN
}

\author{
(Added Value Analysis of Kepok Banana Chips and Kepok Banana Marketing System \\ in Pesawaran Regency)
}

Novia Cahyawati, Bustanul Arifin, Yaktiworo Indriani

\begin{abstract}
Jurusan Agribisnis, Fakultas Pertanian, Universitas Lampung, Jl. Prof. Dr. Soemantri BrodjonegoroNo. 1, Bandar Lampung, 35145, email: bustanul.arifin@fp.unila.ac.id
\end{abstract}

\begin{abstract}
The purpose of this research was to analyze the added value of 'kepok' banana chips, banana marketing system, and to examine the marketing mix of kepok banana chips in agroindustry in Karang Anyar Village, Gedong Tataan District of Pesawaran Regency. The respondents consisted of five owners of banana chipsagroindustry, 12 banana traders, and 35 farmers. Data were collected in October - December 2018, and analyzed using qualitative and quantitative descriptive method. The results showed that chocolate banana chips has greater added value than original and caramel banana chips. The marketing system of Kepok banana is not efficient and tends to be oligopsonistics. The marketing mix in the Kepok banana chips agroindustry follows the four principles of product, prices, places, and promotions. However, location of agroindustry is not strategic and promotions useonly a personal selling method.
\end{abstract}

Key words: added value, banana chips, marketing.

\section{PENDAHULUAN}

Sektor industri pertanian merupakan suatu sistem pengelolaan secara terpadu antara sektor pertanian dengan sektor industri guna mendapatkan nilai tambah produk hasil pertanian (Antara 2009). Sektor industri pertanian akan memberikan kontribusi diantaranya dalam penyerapan tenaga kerja dan penciptaan nilai tambah (added value) yang lebih tinggi pada berbagai komoditas yang dihasilkan. Subsektor pertanian yang memiliki prospek yang baik untuk dikembangkan adalah subsektor tanaman hortikultura. Tanaman hortikultura terdiri dari tanaman sayuran, buahbuahan, tanaman obat-obatan dan tanaman hias. Buah pisang merupakan komoditas buah yang memberikan kontribusi terbesar di Indonesia. Menurut BPS Provinsi Lampung (2017), pisang menduduki tempat pertama diantara berbagai jenis buah-buahan baik dari segi sebaran, luas lahan pertanaman, maupun produksi.

Provinsi Lampung menjadi penghasil komoditas pisang kedua di Indonesia, dikarenakan faktor geografis yang mendukung, sehingga cocok untuk membudidayakan buah pisang.Berdasarkan data Dinas Pertanian Tanaman Pangan dan Hortikultura Provinsi Lampung (2017),Kabupaten Pesawaran menjadi sentra produksi pisang tertinggi di Provinsi Lampung yaitu sebesar 626.264 ton dengan luas panen 4.742 .746 ha dan produktivitas sebesar 0,13 ton/ha. Salah satu kecamatan yang menjadi sentra industri makanan ringan di Kabupaten Pesawaran adalah Kecamatan Gedong Tataan di Desa Karang Anyar. Pengolahan pisang yang telah dilakukan yaitu menjadikeripik pisang, namun pengolahannya belum dilakukan secara optimal. Padahal jika dilakukan pengolahan secara optimal akan memberikan nilai tambah yang lebih besar. Teknik pengolahan pisang yang dilakukan masih secara sederhana hanya menggunakan peralatan seadanya.

Aspek pemasaran merupakan salah satu aspek penting pada sistem agribisnis. Mekanisme pemasaran akan menentukan harga di pihak petani. Tinggi rendahnya harga pisang ini berada di tangan lembaga pemasaran. Semakin banyak lembaga pemasaran yang terlibat, maka semakin panjang rantai pemasaran yang terjadi. Hal ini menyebabkan margin pemasaran yang tinggi, sehingga terjadinya perbedaan harga antara produsen (petani) dengan pedagang hingga sampai di tangan konsumen. Pemasaran yang dilakukan agroindustri sudah cukup baik, namun masih belum optimal. Berdasarkan isi uraian sebelumnya, maka tujuan penelitian ini adalah menganalisis nilai tambah keripik pisang kepok, sistem pemasaran pisang yang dipasok ke agroindustri, serta mengetahui bauran pemasaran agroindustri keripik pisang di Desa Karang Anyar Kecamatan Gedong Tataan Kabupaten Pesawaran. 


\section{METODE PENELITIAN}

Metode penelitian yang digunakan adalah metode studi kasus. Penelitian ini dilakukan di Desa Karang Anyar Kecamatan Gedong Tataan Kabupaten Pesawaran. Penentuan lokasi dilakukan secara sengaja (purposive) dengan pertimbangan bahwa Desa Karang Anyar merupakan salah satu sentra industri makanan ringan di Kabupaten Pesawaran.

Sampel terdiri dari agroindustri keripik pisang kepok, pedagang pisang dan petani. Pengambilan sampel agroindustri sebanyak5 agroindustri keripik pisang kepok yang diambil secara sensus. Pengambilan sampel pedagang pisang dilakukan dengan cara snowball sampling dengan mengikuti alur pemasaran dengan titik awal (starting point) adalah agroindustri keripik pisang kepok. Diperoleh sampel pedagang pisang sebanyak 12 orang dengan pertimbangan pedagang yang rutin memasok pisang pada agroindustri. Sampel petani diambil secara sengaja dengan pertimbangan petani yang melakukan usahatani pisang kepok, karena bahan baku yang digunakan pada agroindustri keripik pisang adalah jenis pisang kepok dengan jumlah sampel sebanyak 35 petani. Menurut Supranto (1998), sampel yang tepat untuk kebanyakan penelitian meliputi persyaratan sejumlah elemen (responden) yang lebih besar dari 30 dan kurang dari 500. Waktu pengumpulan data penelitian dilakukan pada bulan OktoberDesember 2018.

Jenis data yang digunakan adalah data primer dan data sekunder. Data primer diperoleh melalui wawancara secara langsung kepada responden dengan menggunakan kuesioner, sedangkan data sekunder diperoleh dari BPS Provinsi Lampung, Dinas Pertanian Tanaman Pangan dan Hortikultura Provinsi Lampung, laporan terpublikasi dan pustaka lainnya. Data penelitian dianalisis secara deskriptif kualitatif dan kuantitatif. Untuk menghitung nilai tambah keripik pisang dilakukan dengan menggunakan metode nilai tambah Hayami pada Tabel 1. Perhitungan nilai tambah pada penelitian ini dilakukan di lima agroindustri keripik pisang di Desa Karang Anyar yang dibagi menjadi tiga kategori berdasarkan rasa keripik pisang yang diolah masing-masing agroindustri. Kategori rasa terdiri dari rasa original yang diolah oleh tiga orang (agroindustri B, C dan D), rasa caramel diolah oleh satu orang (agroindustri A) dan rasa cokelat diolah oleh satu orang (agroindustri E).
Tabel 1. Perhitungan nilai tambah metode Hayami

\begin{tabular}{|c|c|}
\hline Variabel & Formula \\
\hline \multicolumn{2}{|l|}{ Input, Output, Harga } \\
\hline 1. Hasil produksi (kg/produksi) & A \\
\hline 2. Bahan baku (kg/produksi) & B \\
\hline 3. Tenaga kerja (HOK/produksi) & $\mathrm{C}$ \\
\hline 4. Faktor konversi & $\mathrm{D}=\mathrm{A} / \mathrm{B}$ \\
\hline 5. Koefisien tenaga kerja & $\mathrm{E}=\mathrm{C} / \mathrm{B}$ \\
\hline 6. Harga produk & $\mathrm{F}$ \\
\hline $\begin{array}{l}\text { 7. Upah rata-rata tenaga kerja } \\
(\mathrm{Rp} / \mathrm{HOK})\end{array}$ & G \\
\hline \multicolumn{2}{|l|}{ Pendapatan dan Keuntungan } \\
\hline Harga bahan baku (Rp/kg) & $\mathrm{H}$ \\
\hline $\begin{array}{l}\text { 9. Sumbangan input lain } \\
(\mathrm{Rp} / \mathrm{kg} \text { bahan baku) }\end{array}$ & I \\
\hline Nilai output (Rp/kg) & $=\mathrm{D} \times \mathrm{F}$ \\
\hline 11. a. Nilai tambah & $\begin{array}{l}\mathrm{K}=\mathrm{J}-\mathrm{I}-\mathrm{H} \\
\mathrm{J}\end{array}$ \\
\hline 12. a. Imbalan tenaga kerja & $\mathrm{M}=\mathrm{E} \times \mathrm{G}$ \\
\hline b. Bagian tenaga kerja & $\mathrm{N} \%=(\mathrm{M} / \mathrm{K}) \times 100(\%)$ \\
\hline $\begin{array}{l}\text { 13. a. Keuntungan } \\
\text { b. Tingkat keuntungan }\end{array}$ & $\begin{array}{l}\mathrm{O}=\mathrm{K}-\mathrm{M} \\
\mathrm{P} \%=(\mathrm{O} / \mathrm{K}) \times 100(\%)\end{array}$ \\
\hline \multicolumn{2}{|l|}{ Balas jasa untuk faktor produksi } \\
\hline $\begin{array}{l}\text { 14. Margin keuntungan } \\
\text { a. Keuntungan } \\
\text { b. Tenaga kerja } \\
\text { c. Pendapatan }\end{array}$ & $\begin{array}{l}\mathrm{Q}=\mathrm{J}-\mathrm{H} \\
\mathrm{R}=\mathrm{O} / \mathrm{Q} \times 100 \% \\
\mathrm{~S}=\mathrm{M} / \mathrm{Q} \times 100 \% \\
\mathrm{~T}=\mathrm{I} / \mathrm{Q} \times 100 \%\end{array}$ \\
\hline
\end{tabular}

Keterangan :

$\mathrm{A}=$ Output $/$ total produksi pisang yang dihasilkan oleh agroindustri.

$\mathrm{B}=$ Input/bahan baku berupa pisang digunakandalam per produksi.

$\mathrm{C}=$ Tenaga kerja yang digunakan dalam memproduksi keripik pisang dihitung dalam bentukHOK (hari orang kerja) dalam perproduksi.

$\mathrm{F}=$ Harga produk yang berlaku pada periode produksi.

$\mathrm{G}=$ Jumlah upah rata-rata yang diterima oleh pekerja dalam setiap produksi yang dihitung berdasarkan per HOK (hari upah kerja).

$\mathrm{H}=$ Harga input bahan baku utama per kilogram $(\mathrm{kg})$ per produksi.

$\mathrm{I}$ = Sumbangan/biaya input lainnya yang terdiri dari biaya bahan penunjang, biaya transportasi, biaya listrik,dan biaya penyusutan.

Kriteria nilai tambah adalah sebagai berikut.

(a) Jika NT $>0$, berarti pengembangan agroindustri pengolahan keripik pisang memberikan nilai tambah (positif).

(b) Jika NT $<0$, berarti pengembangan agroindustri pengolahan keripik pisang tidak memberikan nilai tambah (negatif). 
Untuk menganalisis efisiensi sistem pemasaran, pangsa produsen menggunakan rumus:

$\mathrm{PS}=\frac{\mathrm{Pf}}{\mathrm{Pr}} \mathrm{x} 100 \%$

Keterangan :

Ps = Harga pisang yang diterima petani (produsen)

Pf = Harga pisang di tingkat petani (produsen)

$\operatorname{Pr}=$ Harga pisang di tingkat konsumen

Secara matematis, marjin pemasaran dirumuskan sebagai berikut :

$\mathrm{m}_{\mathrm{ji}}=\mathrm{P}_{\mathrm{si}}-\mathrm{P}_{\mathrm{bi}}$ atau

$\mathrm{m}_{\mathrm{ji}}=\mathrm{b}_{\mathrm{ti}}+\pi_{\mathrm{i}}$ atau

$\pi_{\mathrm{i}}=\mathrm{m}_{\mathrm{ji}}-\mathrm{b}_{\mathrm{ti}}$

Total marjin pemasaran dirumuskan sebagai berikut:

$\mathrm{Mji}=\sum_{i=1}^{n} m j i$ atau $\mathrm{Mji}=\operatorname{Pr}-\mathrm{Pf}$.

Keterangan:

$\mathrm{m}_{\mathrm{ji}}=$ Marjin lembaga pemasaran tingkat ke-i.

$\mathrm{Mji}=$ Total marjin pada satu saluran pemasaran.

$\mathrm{P}_{\mathrm{si}}=$ Harga penjualan lembaga pemasaran tingkat ke-i.

$\mathrm{P}_{\mathrm{bi}}=$ Harga pembelian lembaga pemasaran tingkat ke-i.

$\mathrm{b}_{\mathrm{ti}}=$ Biaya tataniaga lembaga pemasaran tingkat ke-i.

$\pi_{\mathrm{i}}=$ Keuntungan lembaga pemasaran tingkat ke-i.

$\operatorname{Pr}=$ Harga pada tingkat konsumen.

$\mathrm{Pf}=$ Harga pada tingkat produsen.

$\mathrm{i}=1,2,3 \ldots . . \mathrm{n}$

Penyebaran marjin pemasaran dilihat berdasarkan persentase keuntungan terhadap biaya pemasaran. Jika selisih RPM antar lembaga perantara pemasaran sama dengan nol, maka sistem pemasaran efisien. Jika selisihnya tidak sama dengan nol, maka sistem pemasaran tidak efisien. Ratio profit margin dirumuskan sebagai berikut :

$\mathrm{RPM}=\frac{\pi \mathrm{i}}{\mathrm{bti}}$

Keterangan :

$\mathrm{b}_{\mathrm{ti}}=$ Biaya tataniaga lembaga pemasaran tingkat ke-i

$\pi_{\mathrm{i}}=$ Keuntungan lembaga pemasaran tingkat ke-i

Untuk mengetahui penerapan bauran pemasaran produk keripik pisang pada agroindustri di
Kabupaten Pesawaran berupa 4P yaitu product, price, place, dan promotion menggunakan analisis deskriptif kualitatif.

\section{HASIL DAN PEMBAHASAN}

\section{Karakteristik Responden}

Sebagian besar responden (46,15 persen) berusia antara 33-47 tahun dengan tingkat pendidikan terakhir sekolah dasar (SD). Usia responden termasuk usia produktif, sehingga sangat berpotensi dalam melakukan kegiatan usahanya. Pengalaman usaha, responden antara 1-13 tahun, yang artinya responden baik dari pelaku agroindustri, pedagang maupun petani sudah cukup berpengalaman. Jumlah anggota keluarga antara 4-6 orang dengan persentase sebesar 76,92 persen.

\section{Analisis Nilai Tambah}

Pada Tabel 2 dapat dilihat bahwa hasil perhitungan nilai tambah tertinggi dalam pengolahan satu kilogram buah pisang menjadi keripik pisang original di Desa Karang Anyar adalah agroindustri C sebesar Rp795,76 dengan rasio nilai tambah 19,60 persen, diikuti oleh agroindustri D sebesar Rp493,59 dengan rasio nilai tambah 12,96 persen dan agroindustri B sebesar Rp410,54 dengan rasio nilai tambah 10,26 persen.

Dilihat dari kriteria menurut Reyne dalam Hubeis (1997), rasio nilai tambah pada agroindustri C termasuk kategori nilai tambah sedang, karena rasio nilai tambah antara 15-40 persen, sedangkan agroindustri B dan agroindustri D termasuk kategori nilai tambah rendah, karena rasio nilai tambah kurang dari 15 persen. Apabila dibandingkan dengan penelitian Mubarok, Arsyad, dan Miftah (2015) yang mendapatkan hasil nilai tambah yang diberikan keripik pisang sebesar Rp2.607,53 dengan rasio nilai tambah sebesar 27,04 persen, maka penelitian di Desa Karang Anyar lebih kecil. Perbedaan nilai tambah ini disebabkanoleh harga outputdan jumlah nilai output yang lebih tinggi.

Nilai balas jasa tenaga kerja pada agroindustri B dan agroindustri $\mathrm{C}$ lebih kecil dibandingkandengan nilai keuntungan. Balas jasa tenaga kerja agroindustri B sebesar 9,42 persen dengan nilai keuntungan sebesar 11,10 persendan agroindustri C sebesar 9,68 persen dengan nilai keuntungan sebesar 28,94 persen. Berbeda pada agroindustri D nilai balas jasa tenaga kerja lebih besar yaitu sebesar 13,82 persen dengan nilai keuntungan 
sebesar 13,46 persen. Dilihat dari nilai balas jasa tenaga kerja dengan nilai keuntungan yang diperoleh agroindustri, maka agroindustri di Desa Karang Anyar pada proses produksi keripik pisang original termasuk kategori padat modal. Artinya agroindustri dalam proses produksinya cenderung pada penggunaan mesin-mesin dibandingkan dengan penggunaan tenaga kerja. Pada Tabel 3 dapat dilihat perhitungan nilai tambah keripik pisang dengan pemberian rasa caramel pada agroindustri $\mathrm{A}$ dan rasa cokelat pada agroindustri E.

Nilai tambah pada agroindustri E sebesar Rp1.962,45 dengan rasio nilai tambah 33,71 persen dan agroindustri A memperoleh nilai tambah sebesar Rp524,30 dengan rasio nilai tambah 11,44 persen. Dilihat dari kriteria Reyne dalam Hubeis (1997), besarnya rasio nilai tambah agroindustri E termasuk pada kategori nilai tambah sedang, karena rasio nilai tambah antara 15-40 persen, sedangkan agroindustri A termasuk pada kategori nilai tambah rendah. Apabila dibandingkan dengan penelitian Febriyanti, Affandi, dan Kalsum (2017) pada perolehan nilai tambah keripik pisang skala mikro di Kota Metro yang memperoleh nilai tambah sebesar Rp15.481,97 dengan rasio nilai tambah 59,97 persen, maka penelitian di Desa Karang Anyar lebih kecil. Perbedaan nilai tambah ini dikarenakan harga output pada penelitian Febriyanti et al (2017) lebih tinggi, sehingga nilai tambah yang diperoleh lebih besar.

Nilai balas jasa tenaga kerja pada agroindustri A dalam produksi keripik pisang caramel lebih besar dibandingkan dengan nilai keuntungan yaitu sebesar 17,78 persen dengan nilai keuntungan sebesar 2,51 persen. Berbeda pada agroindustri E dalam proses produksi keripik pisang cokelat nilai balas jasa tenaga kerja lebih kecil dibandingkan dengan nilai keuntungan yaitu sebesar 9,24 persen dengan nilai keuntungan sebesar 42,12 persen.

Dilihat dari nilai balas jasa tenaga kerja dengan nilai keuntungan yang diperoleh agroindustri, maka agroindustri di Desa Karang Anyar pada proses produksi keripik pisang termasuk kategori padat modal. Sesuai dengan penelitian yang dilakukan Simin (2014), hasil penelitian pengolahan buah pisang menjadi keripik pisang termasuk kategori nilai tambah padat modal. Artinya bahwa agroindustri dalam proses produksinya cenderung pada penggunaan mesinmesin dibandingkan dengan penggunaan tenaga kerja.
Tabel 2. Perhitungan nilai tambah keripik pisang original di Desa Karang Anyar

\begin{tabular}{|c|c|c|c|c|}
\hline \multirow{2}{*}{\multicolumn{2}{|c|}{$\begin{array}{ll}\text { No } & \text { Variabel } \\
\text { Input, } & \text { Output, Harga } \\
\end{array}$}} & \multicolumn{3}{|c|}{ Agroindustri } \\
\hline & & \multirow{2}{*}{$\begin{array}{l}\mathrm{B} \\
65,00\end{array}$} & \multirow{2}{*}{$\frac{\mathrm{C}}{67,00}$} & \multirow{2}{*}{$\begin{array}{l}\mathrm{D} \\
60,00\end{array}$} \\
\hline 1 & $\begin{array}{l}\text { Hasil produksi } \\
\text { (kg/produksi) }\end{array}$ & & & \\
\hline 2 & $\begin{array}{l}\text { Bahan baku } \\
\text { (kg/produksi) }\end{array}$ & 325,00 & 330,00 & 315,00 \\
\hline 3 & $\begin{array}{l}\text { Tenaga kerja } \\
\text { (HOK/ } \\
\text { produksi) }\end{array}$ & 1,75 & 1,88 & 2,25 \\
\hline 4 & Faktor konversi & 0,20 & 0,20 & 0,19 \\
\hline 5 & $\begin{array}{l}\text { Koefisien } \\
\text { tenaga kerja }\end{array}$ & 0,005 & 0,006 & 0,007 \\
\hline 6 & $\begin{array}{l}\text { Harga produk } \\
(\mathrm{Rp} / \mathrm{kg})\end{array}$ & $20.000,00$ & $20.000,00$ & $20.000,00$ \\
\hline 7 & $\begin{array}{l}\text { Upah rata-rata } \\
\text { tenaga kerja } \\
(\mathrm{Rp} / \mathrm{HOK})\end{array}$ & $35.000,00$ & $35.000,00$ & $35.000,00$ \\
\hline \multicolumn{5}{|c|}{ Pendapatan dan Keuntungan } \\
\hline 8 & $\begin{array}{l}\text { Harga bahan } \\
\text { baku (Rp/kg) }\end{array}$ & $2.000,00$ & $2.000,00$ & $2.000,00$ \\
\hline 9 & $\begin{array}{l}\text { Sumbangan } \\
\text { input lain (Rp/kg } \\
\text { bahan baku) }\end{array}$ & $1.589,46$ & $1.264,85$ & $1.315,93$ \\
\hline 10 & $\begin{array}{l}\text { Nilai output } \\
(\mathrm{Rp} / \mathrm{kg})\end{array}$ & 0,00 & $4.060,61$ & $3.809,52$ \\
\hline \multirow[t]{2}{*}{11} & $\begin{array}{l}\text { a. Nilai tambah } \\
(\mathrm{Rp} / \mathrm{kg})\end{array}$ & 410,54 & 795,76 & 493,59 \\
\hline & $\begin{array}{l}\text { b. Rasio nilai } \\
\text { tambah (\%) }\end{array}$ & 10,26 & 19,60 & 12,96 \\
\hline \multirow[t]{2}{*}{12} & $\begin{array}{l}\text { a. Imbalan } \\
\text { tenaga kerja } \\
(\mathrm{Rp} / \mathrm{kg})\end{array}$ & 188,46 & 198,86 & 250,00 \\
\hline & $\begin{array}{l}\text { b. Bagian tenaga } \\
\text { kerja }(\%)\end{array}$ & 45,91 & 24,99 & 50,65 \\
\hline \multirow[t]{2}{*}{13} & $\begin{array}{l}\text { a. Keuntungan } \\
(\mathrm{Rp} / \mathrm{kg})\end{array}$ & 222,08 & 596,89 & 243,59 \\
\hline & $\begin{array}{l}\text { b. Tingkat } \\
\text { keuntungan (\%) }\end{array}$ & 54,09 & 75,01 & 49,35 \\
\hline \multicolumn{5}{|c|}{ Balas jasa untuk faktor produksi } \\
\hline \multirow[t]{4}{*}{$\overline{14}$} & $\begin{array}{l}\text { Margin } \\
\text { keuntungan } \\
(\mathrm{Rp} / \mathrm{kg})\end{array}$ & $2.000,00$ & $2.060,61$ & $1.809,52$ \\
\hline & $\begin{array}{l}\text { a. Keuntunga } \\
\mathrm{n}(\%)\end{array}$ & 11,10 & 28,97 & 13,46 \\
\hline & $\begin{array}{l}\text { b.Tenaga } \\
\text { kerja }(\%)\end{array}$ & 9,42 & 9,65 & 13,82 \\
\hline & $\begin{array}{l}\text { c. Input Lain } \\
(\%)\end{array}$ & 79,47 & 61,38 & 72,72 \\
\hline
\end{tabular}

Berdasarkan kriteria penilaian nilai tambah dapat diartikan bahwa kelima agroindustri memberikan nilai tambah positif. Artinya usaha pengolahan buah pisang menjadi keripik pisang layak untuk dikembangkan dan yang memperoleh nilai tambah tertinggi yaitu agroindustri $\mathrm{E}$ yang memproduksi keripik pisang cokelat dibandingkan dengan agroindustri lainnya yang memproduksi keripik pisang rasa original dan caramel. 
Tabel 3. Perhitungan nilai tambah keripik pisang caramel dan cokelat di Desa Karang Anyar

\begin{tabular}{|c|c|c|c|}
\hline No. & Variabel & \multicolumn{2}{|c|}{ Agroindustri } \\
\hline \multicolumn{2}{|c|}{ Input, Output, Harga } & $\mathrm{A}$ & $\mathrm{E}$ \\
\hline 1. & $\begin{array}{l}\text { Hasil produksi } \\
\text { (kg/produksi) }\end{array}$ & 55,00 & 65,00 \\
\hline 2. & $\begin{array}{l}\text { Bahan baku } \\
\text { (kg/produksi) }\end{array}$ & 300,00 & 335,00 \\
\hline 3. & $\begin{array}{l}\text { Tenaga kerja } \\
\text { (HOK/produksi) }\end{array}$ & 3,94 & 3,38 \\
\hline 4. & Faktor konversi & 0,18 & 0,19 \\
\hline 5. & Koefisien tenaga kerja & 0,013 & 0,010 \\
\hline 6. & Harga produk $(\mathrm{Rp} / \mathrm{kg})$ & $25.000,00$ & $30.000,00$ \\
\hline 7. & $\begin{array}{l}\text { Upah rata-rata tenaga } \\
\text { kerja }(\mathrm{Rp} / \mathrm{HOK})\end{array}$ & $35.000,00$ & $35.000,00$ \\
\hline \multicolumn{4}{|c|}{ Pendapatan dan Keuntungan } \\
\hline 8. & Harga bahan baku $(\mathrm{Rp} / \mathrm{kg})$ & $2.000,00$ & $2.000,00$ \\
\hline 9. & $\begin{array}{l}\text { Sumbangan input lain } \\
\text { (Rp/kg bahan baku) }\end{array}$ & $2.059,04$ & $1.858,45$ \\
\hline 10. & Nilai output $(\mathrm{Rp} / \mathrm{kg})$ & $4.583,33$ & $5.820,90$ \\
\hline \multirow[t]{2}{*}{11.} & a. Nilai tambah $(\mathrm{Rp} / \mathrm{kg})$ & 524,30 & $1.962,45$ \\
\hline & b. Rasio nilai tambah (\%) & 11,44 & 33,71 \\
\hline \multirow[t]{2}{*}{12.} & $\begin{array}{l}\text { a. Imbalan tenaga } \\
\text { kerja }(\mathrm{Rp} / \mathrm{kg})\end{array}$ & 459,38 & 353,13 \\
\hline & b. Bagian tenaga kerja(\%) & 87,62 & 17,99 \\
\hline \multirow[t]{2}{*}{13.} & a. Keuntungan $(\mathrm{Rp} / \mathrm{kg})$ & 64,92 & $1.609,31$ \\
\hline & b. Tingkat keuntungan $(\%)$ & 12,38 & 82,01 \\
\hline \multicolumn{4}{|c|}{ Balas jasa untuk faktor produksi } \\
\hline \multirow[t]{4}{*}{14.} & $\begin{array}{l}\text { Margin keuntungan } \\
(\mathrm{Rp} / \mathrm{kg})\end{array}$ & $2.583,33$ & $3.820,90$ \\
\hline & a. Keuntungan $(\%)$ & 2,51 & 42,12 \\
\hline & b. Tenaga kerja $(\%)$ & 17,78 & 9,24 \\
\hline & c. Input Lain (\%) & 79,70 & 48,64 \\
\hline
\end{tabular}

\section{Analisis Pemasaran}

a. Struktur pasar

Pelaku pasar yang terlibat dalam tataniaga pisang kepok terdiri dari petani yang berperan sebagai produsen, pedagang pengumpul dan agroindustri. Struktur pasar yang dihadapi oleh petani pisang kepok di Kabupaten Pesawaran adalah pasar oligopsoni. Hal ini dikarenakan jumlah petani lebih banyak daripada jumlah pedagang yang terlibat. Jumlah pedagang yang sedikit menjadikan harga lebih banyak ditentukan oleh pedagang, sehingga posisi tawar petani menjadi lemah dan bertindak sebagai price taker. Struktur pasar yang dihadapi oleh pedagang pengumpul adalah pasar oligopsoni. Komoditas yang diperjualbelikan bersifat homogen yaitu pisang. Proses penentuan harga didasarkan pada proses tawar-menawar dengan informasi harga yang diperoleh dari sesama pedagang pengumpul.

\section{b. Perilaku pasar}

Perilaku pasar adalah pola tingkah laku dari lembaga tataniaga dalam hubungannya dengan sistem pembentukan harga dan praktik melakukan pembelian dan penjualan, secara horizontal maupun vertikal (Hasyim 2012). Hasil penelitian menunjukkan bahwa hasil panen dijual langsung ke pedagang pengumpul. Hal ini dikarenakan pedagang berasal dari daerah yang sama dengan petani pisang, sehingga petani tidak perlu mengeluarkan biaya tambahan dalam pemasaran pisang. Sistem pembayaran antara petani dengan pedagang secara tunai. Proses pembentukan harga pisang pada daerah penelitian antara petani dengan pedagang pengumpul didasarkan atas harga yang berlaku di pasaran, walaupun terkadang terjadi proses tawar-menawar terlebih dahulu. Hal yang sama dalam pembentukan harga pisang antara pedagang pengumpul dengan agroindustri didasarkan atas harga yang berlaku atau harga yang sudah ditentukan pedagang. Sistem pembayaran antara pedagang dengan agroindustri dilakukan secara tunai setelah transaksi selesai.

c. Keragaan pasar

Indikator yang digunakan untuk menganalisis keragaan pasar adalah saluran pemasaran, margin pemasaran dan ratio profit margin.

\section{(1) Saluran pemasaran}

Lembaga pemasaran yang terlibat dalam kegiatan pemasaran pisang kepok di Kabupaten Pesawaran hanyalah petani pisang dengan pedagang pengumpul, kemudian konsumen akhir pada penelitian ini adalah agroindustri. Saluran yang dilalui dalam pemasaran pisang di daerah penelitian tersaji pada Gambar 1.

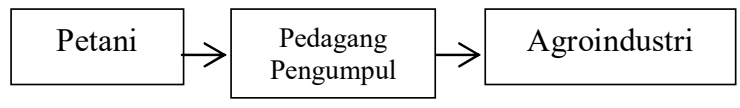

Gambar 1. Saluran pemasaran pisang kepok di Kabupaten Pesawaran

Tabel 4. Analisis margin pemasaran pisang kepok di Kabupaten Pesawaran

\begin{tabular}{llrrr}
\hline No & \multicolumn{1}{c}{ Keterangan } & $\begin{array}{c}\text { Harga } \\
(\mathrm{Rp} / \mathrm{kg})\end{array}$ & $\begin{array}{c}\text { Pangsa } \\
(\%)\end{array}$ & $\begin{array}{l}\text { RPM } \\
(\%)\end{array}$ \\
\hline 1 & Harga jual petani & $1.087,15$ & 52,22 & \\
2 & Pedagang pengumpul & & & 0,92 \\
& a. Harga beli & $1.087,15$ & 52,22 & \\
& b.Biaya Transportasi & 518,25 & 24,89 & \\
& c. Margin & 994,79 & 47,78 & \\
& d. Keuntungan & 476,54 & 22.89 & \\
& e. Harga jual & $2.081,94$ & 100,00 & \\
3 & Agroindustri & & & \\
& Harga Beli & $2.081,94$ & & \\
\hline
\end{tabular}




\section{(2) Margin pemasaran}

Analisis margin pemasaran pisang kepok dapat dilihat pada Tabel 4. Harga jual rata-rata petani pisang kepada pedagang pengumpul sebesar Rp1.087,15 per kg, sehingga pangsa yang diterima petani terhadap harga agroindustri adalah 52,22 persen. Pangsa produsen merupakan bagian harga yang dibayar konsumen akhir yang diterima oleh petani. Semakin tinggi pangsa produsen, maka dianggap bahwa pemasaran semakin efisien (Hasyim 2012).

Harga jual rata-rata pada pedagang pengumpul sebesar Rp2.081,94per kg. Pedagang pengumpul mengeluarkan biaya pemasaran yaitu biaya transportasi rata-rata sebesar Rp518,25per kgyang dikeluarkan pedagang dari lokasi pedagang sampai di tangan agroindustri. Hasil penelitian menunjukkan bahwa keuntungan yang diperoleh pedagang sebesar Rp476,54 per kg.RPM yang diperoleh dari hasil penelitian per kilogram sebesar Rp0,92 yang berarti bahwa setiap Rp1.000,00 yang dikeluarkan oleh pedagang pengumpul, maka akan mendapatkan keuntungan sebesar Rp920,00.

Hasil RPM pada lembaga pemasaran memperoleh nilai tidak sama dengan nol dan tidak menyebar secara merata. Menurut Sudiyono (2004), efisiensi pemasaran terjadi apabila biaya pemasaran dapat ditekan, sehingga keuntungan pemasaran dapat lebih tinggi. Pada penelitian ini, biaya pemasaran lebih besar dari keuntungan yang diperoleh dan nilai RPM tidak sama dengan nol, maka menunjukkan bahwa pemasaran pisang kepok di daerah penelitian belum efisien.

\section{Bauran Pemasaran Agroindustri}

Menurut Kotler (2005), terdapat empat unsur dari bauran pemasaran (4P) yang terdiri dari produk (product), harga (price), tempat (place), dan promosi (promotion). Untuk produk, bentuk dan ukuran keripik pisang ke lima agroindustri keripik pisang di Desa Karang Anyar dibuat sesuai dengan permintaan konsumen. Kemasan yang digunakan agroindustri keripik pisang adalah bungkusan plastik dengan ukuran lima kilogram. Agroindustri belum mempunyai label atau merek, karena mayoritas pembelian produk keripik pisang dalam jumlah grosir, sehingga kemasan yang diperlukan dalam ukuran besar. Lama ketahanan keripik pisang adalah sekitar satu bulan dengan kemasan yang baik dan tertutup rapat.

Penentuan harga agroindustri keripik pisang di Desa Karang Anyar berdasarkan perhitungan biaya operasional dalam memproduksi keripik pisang. Harga keripik pisang rasa cokelat sebesar Rp30.000,00 per kg. Harga keripik pisang cokelat lebih mahal dibandingkan dengan harga keripik pisang original dan keripik pisang caramel, karena menambahkan bubuk perasa, sehingga biaya operasional yang dikeluarkan lebih besar dibandingkan keripik pisang lainnya. Keripik pisang rasa original ditetapkan harga sebesar Rp20.000,00 per kg, sedangkan keripik pisang rasa caramel ditetapkan harga sebesar Rp25.000,00. Sistem pembayaran dilakukan secara tunai dengan tujuan untuk meminimalisasi kerugian. Hal ini sejalan dengan penelitian Kusumawaty (2018) tentangstrategi pemasaran produk makanan ringan Khas Riau (keripik nenas dan rengginang ubi kayu) yang menunjukkan bahwa penetapan harga berdasarkan biaya produksi yang dikeluarkan agroindustri dalam pembuatan keripik nenas dan rengginang ubi kayu, namun harga pada pedagang pengecer lebih besar, karena terdapat biaya angkut, sehingga terdapat perbedaan harga jual di agroindustri dengan pedagang pengecer.

Frekuensi penjualan keripik pisang yang paling banyak yaitu agroindustri A sebanyak 4-5 kali dalam seminggu. Agroindustri B, C, D dan E melakukan penjualan sebanyak 3-4 kali dalam seminggu. Keripik pisang yang telah diproduksi oleh agroindustri secara langsung dibeli oleh pedagang besar dan pedagang pengecer. Lokasi agroindustri keripik pisang yang belum strategis, karena berada di dalam gang dan juga tidak tersedia transportasi umum serta ada beberapa akses jalanan yang rusak.

Metode promosi yang dilakukan agroindustri keripik pisang di Desa Karang Anyar masih secara sederhana dengan menggunakan metode personal selling yaitu dengan cara menawarkan produk keripik pisang secara langsung ke beberapa pedagang makanan ringan di sekitar agroindustri dan pedagang yang berada di pasar atau melalui mulut ke mulut. Hal ini sejalan dengan penelitian Nuraeni dan Harnanik (2017) tentang strategi bauran pemasaran usaha kecil keripik nangka bahwa strategi promosi yang dilakukan secara mouth to mouth (mulut ke mulut) dan cara ini dirasakan cukup efektif dalam menarik konsumen.

\section{KESIMPULAN}

Agroindustri keripik pisang di Desa Karang Anyar bernilai tambah positif, sehingga layak untuk diusahakan. Nilai tambah tertinggi ada pada agroindustri E yang memproduksi keripik pisang 
cokelat dengan nilai tambah sebesar Rp1.962,45 dengan rasio nilai tambah sebesar 33,71 persen yang memberikan nilai tambah yang paling besar dibandingkan dengan keripik pisang original dan keripik pisang caramel. Sistem pemasaran pisang kepok belum efisien dengan struktur pasar oligopsoni. Bauran pemasaran pada agroindustri keripik pisang kapok telah menerapkan $4 \mathrm{P}$ yang terdiri dari produk, harga, tempat dan promosi, namun pada unsur promosi belum dilakukan secara efektif, karena promosi hanya menggunakan metode personal selling (mulut ke mulut) dan letak lokasi agroindustri yang masih belum strategis. Bentuk, ukuran dan tekstur keripik pisang sudah memenuhi permintaan konsumen dan sesuai selera konsumen dan harga produk ditentukan berdasarkan perhitungan biaya operasional.

\section{DAFTAR PUSTAKA}

Antara M. 2009. Pertanian Bangkit atau Bangkrut. Arti Foundation. Denpasar.

BPS [Badan Pusat Statistik] Provinsi Lampung. 2017. Provinsi Lampung Dalam Angka 2017. BPS Provinsi Lampung. Bandar Lampung.

Dinas Pertanian Tanaman Pangan dan Hortikultura Provinsi Lampung. 2017. Kinerja Tanaman Pangan dan Hortikultura Provinsi Lampung Tahun 2012-2016. Dinas Pertanian Tanaman Pangan dan Hortikultura Provinsi Lampung. Bandar Lampung.

Febriyanti, Affandi MI, dan Kalsum U.2017. Analisis finansial dan nilai tambah agroindustri keripik pisang skala UMK di Kota Metro. JIIA, 5(1): 48-56. http://jurnal.fp.unila.ac.id/index.php/JIA/arti cle/view/1674/1500.[3 Agustus 2018].
Hasyim AI. 2012. Tataniaga Pertanian. Universitas Lampung. Bandar Lampung.

Hubeis M. 1997. Menuju Industri Kecil Profesional di Era Globalisasi Melalui Pemberdayaan Manajemen Industri. Orasi Ilmiah. Fakultas Teknologi Pertanian. Institut Pertanian Bogor. Error! Hyperlink reference not valid.. [7 Agustus 2018].

Kotler P. 2005. Manajemen Pemasaran. PT. Indeks Kelompok Gramedia. Jakarta.

Kusumawaty Y. 2018. Strategi pemasaran produk makanan ringan Khas Riau (keripik nenas danrengginang ubi kayu). Jurnal Agribisnis, 20 (2): 124-138. Error! Hyperlink reference not valid.publication/331706094.[28 Juli 2019].

Mubarok AA, Arsyad A, dan Miftah H. 2015. Analisis nilai tambah dan margin pemasaran pisang menjadi olahan pisang. Jurnal Pertanian, 6(1): 1-14. Error! Hyperlink reference not valid.index.php/jp/article/view/39.[7 Agustus 2018].

Nuraeni L dan Harnanik. 2017. Strategi bauran pemasaran usaha kecil Keripik Bhineka di Desa Belendung Kecamatan Purwadadi Kabupaten Subang. Economic Education Anaysis Journal (EEAJ), 6(2): 647-655. http://journal.unnes.ac.id/sju/index.php/eeaj/ article/view/16453/8551.[28 Juli 2019].

Simin I. 2014. Analisis nilai tambah buah pisang menjadi keripik pisang pada industri rumah tangga Sofie di Kota Palu. Agrotekbis, 2(5): 510-516. https://www.neliti.com/id/ publications/243833.[ 3 Agustus 2018].

Sudiyono A. 2004. Pemasaran Pertanian. UMM Press Malang. Malang.

Supranto J. 1998. Teknik Sampling untuk Survei dan Eksperimen. Rineka Cipta. Jakarta. 